\title{
Effect of Applied Bio-fertilizers, Seaweed Extract \\ and Elemental Sulphur on Productivity of Sunflower Grown in Newly Reclaimed Slightly Saline Soil
}

\author{
N. R. Habashy and Mounira M. Bishara \\ Soils, Water and Environment Research Institute, Agriculture \\ Research Center, Giza, Egypt.
}

\begin{abstract}
A
FIELD experiment was conducted during two successive seasons on a slightly saline sandy clay loam soil calcareous in nature at a newly reclaimed area comprising the desert zone of El-Fayoum district, El-Fayoum Governorate, Egypt, located between latitude $29^{\circ} 21^{\prime} 48^{\prime \prime} \mathrm{N}$ longitude $30^{\circ} 44^{\prime} 45^{\prime \prime} \mathrm{E}$. The main target of this study was to identify the positive effects of applied elemental sulphur (i.e, at the rates of $0,200,350$ and $450 \mathrm{~kg} \mathrm{fed}^{-1}$, as soil application), seed bioinoculation (i.e., P-dissolving bacteria of Bacillus megatherium var. phosphaticum) and seaweed extract (at the rate $1.0 \mathrm{~kg} \mathrm{fed}^{-1}$ with 400 liter water as foliar application) either solely or combined treatments on sunflower (Helianthus annuns, c.v. Hysun 336). Growth criteria, i.e., plant height, number of leaves/plant as well as dry matter weight/plant and leaf content of total chlorophyll were determined after 50 days of sowing. At harvest yield and yield components as head diameter, 100 seeds weight, seeds weight fed $^{-1}$, seed oil, protein and nutrient contents were also determined. Some soil properties, i.e., soil $\mathrm{pH}, \mathrm{ECe}, \mathrm{ESP}$ and available macro and micronutrient contents were also takes into consideration. Samples of the plants rhizosphere were collected after 50 and 90 days of sowing to determine $\mathrm{CO}_{2}$ evolution, dehydrogenases activity and total bacterial counts.
\end{abstract}

Data showed a clear response for studied soil properties as well as soil nutritional status as a result of the applied treatments, particularly those treated with the highest rate of elemental sulphur in combination with bio-fertilizer and foliar seaweed extract. The best and achieved greatest values of growth and nutritional status of plants, particularly at early flowering stage were associated with plants subjected to the combined treatments compared to the other solely ones, which positively reflected on seed yield and its quality (oil and protein content). In general, the values of plant parameters were optimized, for bio-inoculated, with increasing the applied elemental sulphur rate 350 or $450 \mathrm{~kg} \mathrm{fed}^{-1}$, with insignificant difference.

The results also, showed that inoculation with P-dissolving bacteria in presence of different elemental sulphur levels combined with foliar seaweed extract encouraged the total bacterial counts, $\mathrm{CO}_{2}$ evolution and dehydrogenase activity at 50 and 90 days. 
So that, it could be recommended that elemental sulphur, seed bioinoculation with P-dissolving bacteria and seaweed extract as foliar application may be used to alleviate the hazardous effects of saline soil calcareous in nature, on sunflower seed yield and its quality.

Keywords: Alkaline soil, Elemental sulphur, Bio-fertilizer, P-dissolving bacteria and sunflower plant.

Sunflower (Helianthus annuus L.) is an important oil seed crop worldwide, and it is an important crop in Mediterranean areas where salinity is an increasing problem (Di et al., 2007). Sunflower is moderately sensitive to soil salinity; the promotion of sunflower could be successful to increase the domestic production provided proper cultivars are available which are suitable to different soil and climatic conditions (Khatoon et al., 2000). Egyptian desert soils calcareous in nature are generally characterized by alkaline condition, and then available nutrient contents are surveyed as low levels. So, soil fertilization management practices are ones of the most important agro-management factors that affect the yield and its components of the different crops, especially those grown on the newly reclaimed desert soils (Patel and Shelke, 1998).

Sunflower has a relatively high nutrient requirements and most soils which the crop is grown are deficient in one or more nutrients for optimum seed yield, oil and protein content. Phosphorus is needed during the earliest stage of plant growth. Any $\mathrm{P}$ deficiency during early growth can great reduce yield potential of tops and seeds. Therefore, the amount of $\mathrm{P}$ in sunflower seeds can be important to help seedling establishment and in determining final seed yields (Bolland, 1997).

Many solutions were executed to reduce the previously mentioned problems, out of them using bio-fertilization with P-dissolving bacteria and the application of elemental sulphur to the soil. The later is emphasized by the statement of $\mathrm{P}$ availability is a function of either soil $\mathrm{pH}$ or $\mathrm{CaCO}_{3}$ content, and the application of sulphur increased the nutrients availability, particularly $\mathrm{P}$ and micronutrients in the soil .These findings are in harmony by those outlined by Azer et al. (2003) who reported a significant response in seed yield, crude protein and $\mathrm{P}$ contents.

Sulphur is the fourth major nutrient in crop production. Elemental $\mathrm{S}$ has been used for many years in the reclamation and improvement of sodic and calcareous soils (Wassif et al., 1993). More attention has been given to sulphur application to soils due to its favorable effects in promoting nutrient availability in soils (Saleh, 2001). Application of sulphur as amendment for alkaline and/or calcareous soils has received little attention, as an inhibitor for ammonia volatilization (Abdou et al., 2011). The nutrient availability of soils can be increased with the application of S. Thus, there is a growing interest in $S$ applications to improve availability of nutrients and overcome nutrient deficiencies in both alkaline and calcareous soils (Neilsen et al., 1993). Because of the high cost and adverse effects of commercial fertilizers especially $\mathrm{N}, \mathrm{P}$ and $\mathrm{K}$ fertilizers, use of natural sources, micronutrients

Egypt. J. Soil Sci. 53, No. 1 (2013) 
and $\mathrm{S}$ may be used as a nutrient and soil acidifier and $\mathrm{S}$ fertilizer has recently gained importance in agricultural production (Atilgan et al., 2008). An individual application of $\mathrm{S}$ or combined with Fe dropped soil pH in calcareous soil (Abbaspour et al., 2004) but application of $\mathrm{S}$ combined with $\mathrm{N}$ fertilizer significantly increased the availability of micronutrients (Erdal et al., 2004). Sulfur is a constituent of the amino acids cysteine and methionine and part of proteins that plays an important role in the synthesis of vitamins and chlorophyll in the cell (Marschner, 1995 and Kacar \& Katkat, 2007). As a result of S deficiency, plants show retarded growth (Motior et al., 2011) and reduction in yield and quality. The efficacy of $S$ to satisfy the $S$ demand of crops depends, however, on speed and magnitude of its oxidation to $\mathrm{H}_{2} \mathrm{SO}_{4}$ which is taken up by plants (Yang et al., 2010 and Abdou et al., 2011).

The microbial strain such as B.megatherium is one of the most important agents to sustain $\mathrm{P}$ availability in the treated soil. These strain agents are the primary substances controlling the enhanced plant growth, absorption nutrients and photosynthesis process (Makovacki and Milic, 2001). Moreover, seeds inoculation with bio-fertilizer is economically important as it resulted in reducing the needs of $\mathrm{N}$ and P fertilizers and improving the crop yield. Azzam and Omran (2005) found that bio-fertilization improved plant growth characters and seed yield of sunflower plants.

Seaweed extract contained macro nutrients, trace elements, organic substances like amino acids and plant growth regulators such as auxin, cytokinin and gibberellins. They are particularly suitable content ( Chapman and Chapman, 1980). Verkleij (1992) stated that application of seaweed extract enhanced the water retention capacity of soil. Seaweed extracts are known to enhance seed germination and plant growth (Thirumaran et al., 2009). They have been also shown to increase crop yield, improve growth and induce resistance to frost, fungal and insect attack and increase nutrient uptake from soil. The beneficial effect of seaweed extract on terrestrial plants includes improving the overall growth, yield and the ability to with stand adverse environmental conditions (Asirselvin et al., 2004). Abdel-Mawgoud et al. (2010) seaweeds extract was extracts obtained from seaweeds have gained importance as foliar sprays for several crops because the extract contains growth promoting hormones (cytokinins), micronutrients ( $\mathrm{Fe}, \mathrm{Cu}, \mathrm{Zn}, \mathrm{Co}, \mathrm{Mo}, \mathrm{Mn}$ and $\mathrm{Ni}$ ), vitamins and amino acids.

The current work aimed to evaluate the integrated effect of bio-fertilization with Bacillus megatherium ( PDB) potential and elemental sulphur and foliar application of seaweed extract on properties of nutritional status of a newly reclaimed soil calcareous in nature besides the effect of applied treatments on yield and yield components of sunflower.

\section{Material and Methods}

To achieve the aforementioned target, a field experiment was conducted during two successive growing seasons on a slightly saline-sodic sandy clay loam

Egypt. J. Soil Sci. 53, No. 1 (2013) 
soil calcareous in nature at a newly reclaimed area comprising the desert zone of El-Fayoum Governorate, Egypt, located between latitude $29^{\circ} 21^{\prime} 48^{\prime \prime} \mathrm{N}$ and longitude $30^{\circ} 44^{\prime} 45^{\prime \prime}$ E. The main physic-chemical properties and nutritional status of the soil are presented in Table 1 (Page et al., 1982).

TABLE 1. Some physical and chemical properties of the experimental soil.

\begin{tabular}{|c|c|c|c|c|c|c|}
\hline Soil characteristics & Value & \multicolumn{4}{|c|}{ Soil characteristics } & Value \\
\hline Particle size distribution $\%:$ & & \multirow{2}{*}{\multicolumn{4}{|c|}{$\begin{array}{l}\text { Soluble cations (soil paste } \mathrm{mmol}_{\mathrm{c}} \mathrm{L}^{-1} \text { ): } \\
\mathrm{Ca}^{2+}\end{array}$}} & \\
\hline Sand & 51.0 & & & & & 15.3 \\
\hline Silt & 35.0 & \multicolumn{4}{|c|}{$\mathrm{Mg}^{2+}$} & 10.7 \\
\hline Clay & 13.7 & \multicolumn{4}{|c|}{$\mathrm{Na}^{+}$} & 28.2 \\
\hline \multirow{2}{*}{\multicolumn{2}{|c|}{$\begin{array}{l}\text { Textural class } \\
\text { Soil chemical properties: }\end{array}$}} & \multicolumn{4}{|c|}{$\mathrm{K}^{+}$} & 0.6 \\
\hline & & \multicolumn{4}{|c|}{ Soluble anions (soil paste $\mathrm{mmol}_{\mathrm{c}} \mathrm{L}^{-1}$ ): } & \\
\hline $\begin{array}{l}\mathrm{pH} \quad 1: 2.5 \quad \text { (soil water } \\
\text { suspension) }\end{array}$ & 8.15 & \multicolumn{4}{|c|}{$\mathrm{CO}_{3}^{2-}$} & 0.00 \\
\hline $\mathrm{CaCO}_{3} \%$ & 14.0 & \multicolumn{4}{|c|}{$\mathrm{HCO}_{3}^{-}$} & 3.0 \\
\hline Organic carbon $\%$ & 0.99 & \multicolumn{4}{|c|}{$\mathrm{Cl}^{-}$} & 36.1 \\
\hline \multirow[t]{2}{*}{$\mathrm{ECe}\left(\mathrm{dS} \mathrm{m}{ }^{-1}\right.$, soil paste extract $)$} & 5.48 & \multicolumn{4}{|c|}{$\mathrm{SO}_{4}{ }^{2-}$} & 15.7 \\
\hline & & \multicolumn{4}{|c|}{ ESP } & 15.7 \\
\hline \multicolumn{7}{|l|}{ Available nutrients $\mathrm{mg} \mathrm{kg}^{-1}$} \\
\hline $\begin{array}{lll}\mathrm{N} & \mathrm{P} & \mathrm{K}\end{array}$ & K & $\mathrm{S}$ & $\mathrm{Fe}$ & $\mathrm{Mn}$ & $\mathrm{Zn}$ & $\mathrm{Cu}$ \\
\hline 37.15 & & 7.94 & 4.23 & 0.80 & 0.65 & 0.38 \\
\hline
\end{tabular}

The applied treatments comprised different rates of elemental sulphur, i.e., 0 , $200,350,450 \mathrm{~kg} \mathrm{fed}^{-1}$, which were thoroughly mixed with the topsoil during soil preparation, 21 days before sowing followed by light irrigation. Sunflower seeds were inoculated with Bacillus megatherium (PDB) which was obtained from the Dept., Agric . Microbiol., Soil,Water and Environ. Res. Inst. (SWERI), Agric. Res. Center (ARC), Giza, Egypt on the same day of sowing. The inoculation was executed by mixing sunflower seeds with heavy cell suspention of (PDB) (with about $10^{9} \mathrm{cfu} \mathrm{ml}^{-1}$ ). The applied rate of foliar seaweed extract was at $1.0 \mathrm{~kg} \mathrm{fed}^{-1}$ with $400 \mathrm{~L}$ of water. Analysis of seaweed extract used is illustrated in Table 2. Experimental plots $\left(10.5 \mathrm{~m}^{2}\right)$ were arranged in split split plot design with three replicates for each treatment (Gomez and Gomez, 1984).

TABLE 2. Some components of seaweed extract used.

\begin{tabular}{|l|c|c|c|c|c|}
\hline $\begin{array}{l}\text { Organic } \\
\text { Matter } \\
\mathbf{\%}\end{array}$ & $\begin{array}{c}\text { Potassium } \\
\left(\mathbf{K}_{\mathbf{2}} \mathbf{O}\right) \\
\mathbf{\%}\end{array}$ & $\begin{array}{c}\text { Nitrogen } \\
\mathbf{( N )} \mathbf{\%}\end{array}$ & $\begin{array}{c}\text { Phosphorus } \\
\left(\mathbf{P}_{\mathbf{2}} \mathbf{O}_{\mathbf{5}}\right) \mathbf{\%}\end{array}$ & $\begin{array}{c}\text { Free amino } \\
\text { acids }\end{array}$ & $\begin{array}{c}\text { Algenic Acid } \\
\mathbf{\%}\end{array}$ \\
\hline 45 & 12 & 1.5 & 0.8 & $20.4 \mathrm{mg} \mathrm{kg}^{-1}$ \\
\hline $\mathrm{pH}$ & Manitol & $\begin{array}{l}\text { Water } \\
\text { solubility }\end{array}$ & $\begin{array}{l}\text { Cytokinines } \\
\text { Auxins and } \\
\text { Gibberellins }\end{array}$ & Density $\left(\mathrm{g} \mathrm{cm}^{-3}\right)$ & Appearance \\
\hline $4.0-5.0$ & $5 \%$ & $100 \%$ & $600 \mu \mathrm{kg}^{-1}$ & 0.633 & Black powder \\
\hline
\end{tabular}

All sunflower (Helianthus annuns, c.v. Hysun 336) plots received $200 \mathrm{~kg}$ fed $^{-1}$ of single superphosphate $\left(15.5 \% \mathrm{P}_{2} \mathrm{O}_{5}\right), 200 \mathrm{~kg} \mathrm{fed}^{-1}$ ammonium nitrate Egypt. J. Soil Sci. 53, No. 1 (2013) 
$(33.5 \% \mathrm{~N})$ and $50 \mathrm{Kg} \mathrm{fed}^{-1}$ potassium sulphate $\left(48 \% \mathrm{~K}_{2} \mathrm{O}\right)$ which incorporated into the top $15 \mathrm{~cm}$ of the soil during the preparation of soil cultivation. Hill spacing was $10 \mathrm{~cm}$ within the row. Seeds were sown at 3-5 seeds in each hill in the first week of April. Irrigation water was used immediately after sowing, then every one week interval according to agronomic practices in the district. Thinning was carried out at 15 days after sowing to secure two plants per hill on both sides of the ridge.

Three plant samples plot $^{-1}$ were collected 50 days after sowing for determination of the growth criteria plant height, number of leaves plant ${ }^{-1}$ as well as dry weight of plant and leaf chlorophell. At harvest samples were collected for determination of yield components as head diameter, 100 seeds weight, seeds yield $\mathrm{fed}^{-1}$, seed oil \& protein and nutrient contents of N, P, K, S, Fe, Mn, Zn and $\mathrm{Cu}$ according to (Issam and Sayegh, 2007). Two samples of the rhizosphere plants soil were collected after 50 and 90 days of sowing to determine $\mathrm{CO}_{2}$ evolution (Shehata, 1972), dehydrogenase activity (Alef, 1995) and total bacterial counts according to Page et al. (1982).

All collected data were statistically analyzed according to Gomez and Gomez (1984).

\section{Results and Discussion}

As the obtained results of both successive seasons were not significantly different, their average was taken into consideration.

Response of some soil properties and available nutrients to the applied treatments

Some soil properties

In respective of elemental sulphur, Data in Table 3 showed a clearly response of some soil properties, i.e., pH, ECe and ESP to the applied treatments, particularly those treated with the highest rates of elemental sulphur, i.e., 350 or $450 \mathrm{~kg} \mathrm{fed}^{-1}$. That was true, since elemental sulphur can be oxidized by many soil microorganisms and forming sulphuric acid, besides the acidity reacts of the microbial activity of Bacillus megatherium var. phosphaticum itself, consequently such acid media led to lowering soil $\mathrm{pH}$. Also, the created sulphuric acid reacts with the native soil $\mathrm{CaCO}_{3}$ and resulting in $\mathrm{CaSO}_{4}$. The latter can be ionized to $\mathrm{Ca}^{2+}$ and $\mathrm{SO}_{4}{ }^{2-}$, which was also reduced soil $\mathrm{pH}$. These results are in agreement with those obtained by Awadalla et al. (2003).

On the other hand, the released soluble ions of $\mathrm{Ca}^{2+}$ can improve soil aggregation, due to a $\mathrm{Ca}^{2+}$ partial substitution by exchangeable $\mathrm{Na}^{+}$that enhancing the coagulation of Na-separated clay particles and leading to reduce ESP value which encouraging the formation of small clay domains. Such clay domains are coated with soil humified organic substances and then forming coarse pores that are increased soil permeability and accelerating leaching of a pronounced content of excess soluble salts, and then reducing ECe value. The effective role of microbial activity in combination with applied elemental sulphur 
for ameliorating soil properties could be interpreted according to many opinion outlined by Bacilio et al. (2003), Shaban and Omar (2006) and Ashmay et al. (2008) who reported that many strain produce several phytohormones (i.e., indol acetic acid and cytokinins) and organic acid. Such products simultaneously improving soil structure, i.e., increasing aggregate stability and drainable pores. Consequently, these created conductive pores enhancing the leaching process of soluble salts through irrigation fraction.

TABLE 3. Effect of applied treatments on some soil properties.

\begin{tabular}{|c|c|c|c|c|}
\hline \multirow{2}{*}{ *PDB } & \multirow{2}{*}{$\begin{array}{l}\text { E-Sulphur } \\
\left(\mathrm{kg} \mathrm{fed}^{-1}\right)\end{array}$} & \multicolumn{3}{|c|}{ Soil properties } \\
\hline & & pH & $\operatorname{ECe}\left(d S m^{-1}\right)$ & ESP \\
\hline \multicolumn{5}{|c|}{ Without seaweed extract } \\
\hline \multirow{4}{*}{ Un-Inocutation } & 0 & 8.22 & 5.34 & 15.45 \\
\hline & 200 & 7.85 & 5.04 & 14.05 \\
\hline & 350 & 7.34 & 4.56 & 11.00 \\
\hline & 450 & 7.32 & 4.51 & 10.80 \\
\hline \multirow{4}{*}{ Inocutation } & 0 & 8.20 & 5.21 & 15.22 \\
\hline & 200 & 7.78 & 4.56 & 11.52 \\
\hline & 350 & 7.25 & 3.60 & 10.70 \\
\hline & 450 & 7.21 & 3.41 . & 10.30 \\
\hline \multicolumn{5}{|c|}{ With seaweed extract } \\
\hline \multirow{4}{*}{ Un-Inocutation } & 0 & 8.20 & 5.21 & 15.00 \\
\hline & 200 & 7.81 & 4.81 & 14.39 \\
\hline & 350 & 7.34 & 4.12 & 13.00 \\
\hline & 450 & 7.28 & 4.00 & 10.21 \\
\hline \multirow{4}{*}{ Inocutation } & 0 & 8.07 & 5.13 & 14.93 \\
\hline & 200 & 7.72 & 4.32 & 10.80 \\
\hline & 350 & 7.19 & 3.20 & 10.13 \\
\hline & 450 & 7.12 & 3.10 & 10.01 \\
\hline
\end{tabular}

*PDB= P-dissolving bacteria.

\section{Soil available nutrients}

In general, the obtained data presented in Table 4 showed that the beneficial effect of the applied treatments, particularly elemental sulphur at the applied rates of 350 or $450 \mathrm{~kg} \mathrm{fed}^{-1}$, with insignificant differences. That was commonly achieved by lowering soil $\mathrm{pH}$ and in turn encouraging the availability of plant essential nutrients, especially phosphorus as macronutrients and sulphur as well as $\mathrm{Fe}, \mathrm{Mn}, \mathrm{Zn}$ and $\mathrm{Cu}$ as micronutrients. The superiority of combined effect of added elemental sulphur as soil application and bio-fertilizer as P-dissolving bacteria for the noticeable increment in soil available nutrient contents could be attributed to the pronounced decrease in the values of soil $\mathrm{pH}$, ECe and ESP vs the favorable amelioration in soil biological conditions that encouraging the released nutrients from soil native sources in the available forms as well as easily mobility towards plant roots and in turn their uptake by plants. In addition the application of elemental sulphur tend to accelerate the released active inorganic acid $\left(\mathrm{H}_{2} \mathrm{SO}_{4}\right)$ that leads to controlling soil availability and mobility of nutrients, which are more sensitive to the adverseable effects of alkaline soil media.

Egypt. J. Soil Sci. 53, No. 1 (2013) 
TABLE 4 . Effect of applied treatments on soil availability of some nutrient contents.

\begin{tabular}{|c|c|c|c|c|c|c|c|c|c|}
\hline \multirow{3}{*}{$\begin{array}{c}* \text { PDB } \\
\text { (B) }\end{array}$} & \multirow{3}{*}{$\begin{array}{l}\text { E-Sulphur(S) } \\
\left(\mathrm{kg} \mathrm{fed}^{-1}\right)\end{array}$} & \multicolumn{8}{|c|}{ Soil available nutrient contents $\left(\mathrm{mg} \mathrm{kg}^{-1}\right.$ soil) } \\
\hline & & \multicolumn{3}{|c|}{ Macronutrients } & \multirow{2}{*}{$\mathbf{S}$} & \multicolumn{4}{|c|}{\begin{tabular}{|l|} 
Micronutrients \\
\end{tabular}} \\
\hline & & $\mathbf{N}$ & $\mathbf{P}$ & $\mathbf{K}$ & & $\mathbf{F e}$ & Mn & $\mathbf{Z n}$ & $\mathbf{C u}$ \\
\hline \multicolumn{10}{|c|}{ Without seaweed extract $(\mathbf{E})$} \\
\hline \multirow{4}{*}{$\begin{array}{l}\text { Un- } \\
\text { Inocutation }\end{array}$} & 0 & 35.61 & 3.59 & 191.1 & 6.73 & 3.93 & 0.98 & 0.82 & 0.47 \\
\hline & 200 & 41.95 & 4.13 & 201.4 & 8.58 & 4.50 & 1.34 & 1.09 & 0.70 \\
\hline & 350 & 46.10 & 4.47 & 207.0 & 10.85 & 4.78 & 1.61 & 1.23 & 0.81 \\
\hline & 450 & 47.15 & 4.77 & 209.2 & 10.98 & 5.95 & 1.66 & 1.29 & 0.85 \\
\hline \multirow{4}{*}{ Inocutation } & 0 & 37.18 & 5.98 & 199.4 & 8.02 & 4.75 & 1.10 & 1.01 & 0.76 \\
\hline & 200 & 56.19 & 6.74 & 223.3 & 9.34 & 6.13 & 1.34 & 1.44 & 1.17 \\
\hline & 350 & 65.54 & 7.53 & 236.9 & 12.76 & 7.00 & 2.49 & 1.79 & 1.47 \\
\hline & 450 & 66.19 & 8.19 & 241.7 & 12.93 & 7.13 & 2.61 & 1.92 & 1.56 \\
\hline \multicolumn{10}{|c|}{ With seaweed extract } \\
\hline \multirow{4}{*}{$\begin{array}{l}\text { Un- } \\
\text { Inocutation }\end{array}$} & 0 & 36.17 & 4.47 & 196.8 & 6.93 & 4.38 & 1.04 & 0.86 & 0.60 \\
\hline & 200 & 47.31 & 4.89 & 212.2 & 9.87 & 5.43 & 1.49 & 1.32 & 0.94 \\
\hline & 350 & 53.17 & 5.76 & 222.3 & 12.48 & 5.71 & 2.03 & 1.53 & 1.12 \\
\hline & 450 & 55.91 & 5.91 & 224.5 & 12.70 & 5.83 & 2.09 & 1.59 & 1.17 \\
\hline \multirow{4}{*}{ Inocutation } & 0 & 38.12 & 7.31 & 206.0 & 7.08 & 4.13 & 1.07 & 0.89 & 0.57 \\
\hline & 200 & 63.94 & 8.23 & 243.0 & 10.62 & 6.18 & 2.19 & 1.64 & 1.31 \\
\hline & 350 & 74.18 & 8.88 & 254.6 & 13.30 & 7.66 & 2.83 & 2.08 & 1.81 \\
\hline & 450 & 76.30 & 9.24 & 263.9 & 13.68 & 8.24 & 3.01 & 2.19 & 1.89 \\
\hline \multicolumn{10}{|c|}{ ANOVA } \\
\hline \multirow{7}{*}{$\begin{array}{l}\text { LSD } \\
\text { at } 0.05\end{array}$} & $\mathrm{E}$ & 3.40 & 0.12 & 3.70 & 0.14 & 0.90 & 0.12 & 0.02 & 0.01 \\
\hline & B & 2.20 & 0.10 & 2.10 & 0.18 & 0.12 & 0.42 & 0.01 & 0.02 \\
\hline & $S$ & 2.50 & 0.13 & 2.52 & 0.08 & 0.11 & 0.31 & 0.23 & 0.05 \\
\hline & $E \times B$ & 3.10 & 0.14 & 3.36 & 0.07 & 0.09 & 0.50 & 0.02 & 0.01 \\
\hline & $\mathrm{E} \times \mathrm{S}$ & 2.20 & 0.09 & 4.80 & 0.14 & 0.08 & 0.14 & 0.06 & 0.02 \\
\hline & $\mathrm{B} \times \mathrm{S}$ & 2.70 & 0.08 & 2.30 & 0.16 & 0.10 & 0.32 & 0.05 & 0.03 \\
\hline & $\mathrm{E} \times \mathrm{B} \times \mathrm{S}$ & 2.00 & 0.13 & 2.41 & 0.11 & 0.05 & 0.11 & 0.02 & 0.01 \\
\hline
\end{tabular}

*PDB $=$ P-dissolving bacteria.

Consequently, the applied elemental sulphur to the soil plays an important role for its nutritional status, whether be under demand as strategic storehouse for unavailable native nutrients. In this connection, Mohammed (2004) interpreted the integrated role of applied elemental sulphur plus bio-fertilizer, which resulted in more pronounced nutrients availability in the soil, on the basis of lowering soil $\mathrm{pH}$ and microbial activity that enhancing the solublization of nutrient from the native and added sources. Moreover, such prevailing conditions enhance the slow release of nutrients during the mineralization processes as well as minimizing their possible lose by leaching. These finding are also in agreement with Kaplan et al. (2005) who reported that a potential strategy to enhance nutrients availability is the lowering soil $\mathrm{pH}$ that can be achieved through application of acid-producing fertilizers like sulphure-containing materials. 
Total bacterial count, $\mathrm{CO}_{2}$ evolution and dehydrogenase activity in rhizosphere soil

Results in Table 5 revealed that inoculation with P-dissolving bacteria in presence of different elemental sulphur levels encouraged the population of bacterial counts. However, the highest count of those microorganisms was attained by the treatment inoculated and companied with foliar seaweed extract. The corresponding high values were $77 \& 130 \times 10^{5} \mathrm{cfu} \mathrm{g}^{-1}$ soil with foliar seaweed extract and $45 \& 70 \times 10^{5} \mathrm{cfu} \mathrm{g}^{-1}$ soil (total bacterial count) for the treatments without foliar seaweed extract at 50 and 90 days from sowing, respectively.

Data presented in Table 5 indicated that the highest values of both $\mathrm{CO}_{2}$ evolution and dehydrogenase activity were obtained by the treatment inoculated with P-dissolving bacteria in combination with $450 \mathrm{~kg} \mathrm{fed}^{-1}$ elemental sulphure in presence of foliar seaweed extract. The corresponding high values were $699.3 \& 788.0$ $\mathrm{mg} \mathrm{CO}_{2} 100 \mathrm{~g} \mathrm{soil}^{-1}$ soil and $288.0 \& 546.0 \mu \mathrm{gTPF} .100 \mathrm{~g}$ soil day ${ }^{-1}$ (dehydrogenase activity) at 50 and 90 days from sowing, respectively.

TABLE 5. Effect of applied treatments on microbial activity (total bacterial count, $\mathrm{CO}_{2}$ evolution and dehydrogenase activity) in rhizospher soil at 50 and 90 days after sowing .

\begin{tabular}{|c|c|c|c|c|c|c|c|}
\hline \multirow{3}{*}{${ }^{*}$ PDB } & \multirow{3}{*}{$\begin{array}{l}\text { E-Sulphur } \\
\left(\mathrm{kg} \mathrm{fed}^{-1}\right)\end{array}$} & \multicolumn{2}{|c|}{$\begin{array}{c}\text { Total bacteria } \\
\times 10^{5} \mathrm{cfu} \mathrm{g} \mathrm{soil}^{-1}\end{array}$} & \multicolumn{2}{|c|}{$\begin{array}{c}\mathrm{CO}_{2} \\
\left(\mathrm{mg} .100 \mathrm{~g} \mathrm{soil}^{-1}\right)\end{array}$} & \multicolumn{2}{|c|}{$\begin{array}{c}{ }^{\#} \text { DHA } \\
\left(\mu \mathrm{g}_{\text {TPF.100 g soil }}\right. \\
\left.\text { day }^{-1}\right) \\
\end{array}$} \\
\hline & & \multicolumn{6}{|c|}{ days after sowing } \\
\hline & & 50 & 90 & 50 & 90 & 50 & 90 \\
\hline \multicolumn{8}{|c|}{ Without seaweed extract } \\
\hline \multirow{4}{*}{$\begin{array}{l}\text { Un- } \\
\text { Inocutation }\end{array}$} & 0 & 10 & 13 & 120.9 & 123.9 & 18.3 & 86.5 \\
\hline & 200 & 14 & 22 & 141.9 & 159.3 & 22.1 & 145.3 \\
\hline & 350 & 21 & 53 & 218.6 & 340.8 & 28.0 & 275.6 \\
\hline & 450 & 29 & 60 & 253.3 & 371.2 & 64.0 & 261.3 \\
\hline \multirow{4}{*}{ Inocutation } & 0 & 12 & 14 & 156.9 & 167.2 & 30.3 & 80.0 \\
\hline & 200 & 18 & 38 & 186.5 & 273.3 & 40.4 & 124.0 \\
\hline & 350 & 36 & 57 & 228.0 & 404.9 & 48.6 & 187.8 \\
\hline & 450 & 45 & 70 & 328.0 & 439.5 & 112.9 & 339.5 \\
\hline \multicolumn{8}{|c|}{ With seaweed extract } \\
\hline \multirow{4}{*}{$\begin{array}{l}\text { Un- } \\
\text { Inocutation }\end{array}$} & 0 & 13 & 18 & 134.5 & 161.2 & 92.0 & 107.3 \\
\hline & 200 & 18 & 24 & 156.7 & 303.5 & 112.0 & 229.3 \\
\hline & 350 & 40 & 74 & 230.5 & 388.3 & 148.0 & 272.0 \\
\hline & 450 & 51 & 92 & 357.1 & 466.3 & 312.3 & 408.0 \\
\hline \multirow{4}{*}{ Inocutation } & 0 & 16 & 22 & 151.3 & 187.2 & 107.6 & 138.6 \\
\hline & 200 & 34 & 50 & 202.7 & 422.1 & 126.5 & 253.3 \\
\hline & 350 & 48 & 97 & 253.2 & 618.5 & 180.0 & 260.6 \\
\hline & 450 & 77 & 130 & 699.3 & 788.0 & 288.0 & 546.0 \\
\hline
\end{tabular}

$\mathrm{PDB}=\mathrm{P}$-dissolving bacteria. ${ }^{\#}$ Initial dehydrogenase activity (DHA) was $3.9\left(\mu \mathrm{g}\right.$ TPF.100 g soil day $\left.{ }^{-1}\right)$.

Egypt. J. Soil Sci. 53, No. 1 (2013) 
Plant parameters as affected by the associated ameliorating soil properties

Plant growth characters

Data presented in Table 6 indicated that the achieved favorable soil conditions due to the applied treatments, particularly the combined ones of elemental sulphur with either bio-fertilizer (P-dissolving bacteria) or seaweed extract, were positively reflected on studied values of sunflower plant growth characters (i.e., the total leaf of chlorophyll, plant height, number of leaves plant ${ }^{-1}$ and dry matter weight plant $^{-1}$ ) as compared to the applied solely ones. It can be explained on the basis that the treated soil with elemental sulphur and biofertilizer became enriched in the released nutrient contents, especially those of micronutrients, which are involved directly or indirectly in formation of biological components through their roles in the respiratory and photosynthesis mechanisms as well as in the activity of various enzymes (Nassar et al., 2002).

Also, the prmotive effect of the applied seaweed treatment on leaf chemical constituents might be attributed to their enhancing effect on the nutritional status of sunflower plants, and then the increase in dry weight that could be attributed to its stimulating effect on vegetative growth and physiological processes. In addition, the increase of total chlorophyll is owing to that the enhanced nutrients uptake plays an important role for stimulating chlorophyll synthesis enzymes, which reflected on formation of chlorophyll molecule (Abdel-Aziz and El-Shafie, 2005).

Further, it could noticed that the obtained values of the studied plant growth characters tended to gradual increases with increasing the applied rates of elemental sulphur from 0 up to $450 \mathrm{~kg} \mathrm{fed}^{-1}$, with insignificant difference between 350 and $450 \mathrm{~kg} \mathrm{fed}^{-1} \mathrm{~S}$. Also, it is noteworthy to mention that the applied triple treatment of elemental sulphur as a soil amendment at the highest rate $\left(450 \mathrm{~kg} \mathrm{fed}^{-1}\right)$ in combination with bio-fertilizer plus foliar application of seaweed was achieved the greatest values of the tested plant growth characters, with insignificant difference with the applied sulphur rate of $300 \mathrm{~kg} \mathrm{fed}^{-1}$. It is also interpreted to have favorable effect of chlorophyll synthesis resulting in more number of leaves with bigger size and higher chlorophyll content. Thus, sulphur helps in increasing the photosynthetic activity of plant (Upasami and Shama, 1986). In addition, combining bio-fertilizer with sulphur that lead to a markedly increase in the tested growth characters, may be due to their outcomes are essentially for certain of protoplasm, and hence producing new cells and new leaves of sunflower plants that lead to a larger leaf area available for photosynthesis and increase dry matter accumulation (Omran and Azzam, 2007). Sangeetha and Thevanathan (2010) reported that application of seaweed extract increase in linear growth of the shoots and roots was associated with a concomitant increase in the number of lateral roots produced, the number of leaves or leaflets produced, increase in leaf area, increase in the chlorophyll a/b and $\mathrm{C} / \mathrm{N}$ ratio. 
TABLE 6. Effect of applied treatments on some plant growth characters 50 day after

\begin{tabular}{|c|c|c|c|c|c|}
\hline $\begin{array}{l}\text { *PDB } \\
\text { (B) }\end{array}$ & $\begin{array}{l}\text { E-Sulphur(S) } \\
\left(\mathrm{kg} \mathrm{fed}^{-1}\right)\end{array}$ & $\begin{array}{c}\text { Plant } \\
\text { height } \\
(\mathbf{c m})\end{array}$ & $\begin{array}{l}\text { No. of } \\
\text { leaves } \\
\text { plant }^{-1}\end{array}$ & $\begin{array}{c}\text { Leaf } \\
\text { chlorophyll } \\
\left(\mathrm{mg} \mathrm{g}^{-1} \text { fresh }\right. \\
\text { weight) }\end{array}$ & $\begin{array}{c}\text { Dry matter } \\
\text { weight } \\
\left.\text { (g plant }^{-1}\right)\end{array}$ \\
\hline \multicolumn{6}{|c|}{ Without seaweed extract $(\mathbf{E})$} \\
\hline \multirow{4}{*}{$\begin{array}{l}\text { Un- } \\
\text { Inocutation }\end{array}$} & 0 & 76.7 & 10.9 & 0.174 & 7.3 \\
\hline & 200 & 81.3 & 11.1 & 0.200 & 9.9 \\
\hline & 350 & 89.4 & 13.7 & 0.217 & 10.8 \\
\hline & 450 & 90.9 & 14.0 & 0.221 & 11.4 \\
\hline \multirow{4}{*}{ Inocutation } & 0 & 73.1 & 11.5 & 0.200 & 9.5 \\
\hline & 200 & 82.0 & 14.7 & 0.231 & 11.2 \\
\hline & 350 & 94.5 & 15.4 & 0.275 & 13.0 \\
\hline & 450 & 97.8 & 16.5 & 0.279 & 13.5 \\
\hline \multicolumn{6}{|c|}{ With seaweed extract } \\
\hline \multirow{4}{*}{$\begin{array}{l}\text { Un- } \\
\text { Inocutation }\end{array}$} & 0 & 87.6 & 11.2 & 0.199 & 8.9 \\
\hline & 200 & 90.0 & 16.9 & 0.237 & 10.7 \\
\hline & 350 & 93.5 & 17.7 & 0.296 & 11.8 \\
\hline & 450 & 96.7 & 19.2 & 0.301 & 12.9 \\
\hline \multirow{4}{*}{ Inocutation } & 0 & 81.2 & 12.0 & 0.219 & 10.5 \\
\hline & 200 & 100.1 & 15.7 & 0.279 & 12.7 \\
\hline & 350 & 102.7 & 18.2 & 0.307 & 14.8 \\
\hline & 450 & 107.4 & 20.1 & 0.317 & 15.2 \\
\hline \multicolumn{6}{|c|}{ ANOVA } \\
\hline \multirow{7}{*}{$\begin{array}{l}\mathrm{LSD} \\
\text { at } 0.05\end{array}$} & $\mathrm{E}$ & 2.3 & 0.9 & 0.111 & 0.5 \\
\hline & B & 1.5 & 0.7 & 0.213 & 0.4 \\
\hline & $\mathrm{S}$ & 3.2 & 0.2 & 0.211 & 0.3 \\
\hline & $E \times B$ & 4.2 & 0.6 & 0.114 & 0.4 \\
\hline & $\mathrm{E} \times \mathrm{S}$ & 1.3 & 0.3 & 0.200 & 0.3 \\
\hline & $\mathrm{B} \times \mathrm{S}$ & 1.6 & 0.4 & 0.231 & 0.2 \\
\hline & $\mathrm{E} \times \mathrm{B} \times \mathrm{S}$ & 3.1 & 0.3 & 0.112 & 0.4 \\
\hline
\end{tabular}

*PDB= P-dissolving bacteria.

Nutrient contents in plant tissue as affected by the applied treatments

The obtained data of the studied macro-(N, P and K), S and micro-nutrients $(\mathrm{Fe}, \mathrm{Mn}, \mathrm{Zn}$ and $\mathrm{Cu})$ contents in the plant tissues of sunflower are presented in Table 7.

The obtained results exhibited pronounced increases for the studied macronutrients, $\mathrm{S}$ and micronutrients due to the applied elemental sulphur as a solely treatment, with greatest values when it was combined with both $\mathrm{P}$ dissolving bacteria and foliar seaweed extract. Undoubtedly, the applied solely treatments were usefulness as compared to the combine one for the plant tissue contents of the studied nutrients. That was true, since the nutrients uptake by plants are more related to the released available nutrients and their easily mobility towards the plant roots. Such surpassed effects were more associated

Egypt. J. Soil Sci. 53, No. 1 (2013) 
with ameliorated soil $\mathrm{pH}$ due to the applied elemental sulphur and biological activity and their released activity substances that enhancing nutrients solubilization from both native and added sources, besides the favorable biological conditions that are keeping them in available forms and their mobility for uptake by plant roots. In this concern, Abdallah et al. (2010) showed that sulphur deficiency for field grown oilseed rape can reduce nitrogen use efficiency (NUE) and that nitrogen deficiency can also reduce sulphur use efficiency (SUE).

Further, such favored better micronutrient uptakes are in harmony with results obtained by Abdel-Mawgoud et al. (2010) who found that the extracts obtained from seaweeds have gained importance as applied for several crops because the extract contains micronutrients ( $\mathrm{Fe}, \mathrm{Cu}, \mathrm{Zn}, \mathrm{Mn}$ and $\mathrm{Mo}$ ) and amino acids.

TABLE 7. Effect of applied treatments on nutrient contents in sunflower plants.

\begin{tabular}{|c|c|c|c|c|c|c|c|c|c|}
\hline \multirow{2}{*}{ *PDB (B) } & \multirow{2}{*}{$\begin{array}{l}\text { E-Sulphur (S) } \\
\left(\mathrm{kg} \mathrm{fed}^{-1}\right)\end{array}$} & \multicolumn{3}{|c|}{ Macronutrients (\%) } & \multirow{2}{*}{$\begin{array}{l}S \\
(\%)\end{array}$} & \multicolumn{4}{|c|}{ Micronutrients (mg g ${ }^{-1}$ ) } \\
\hline & & $\mathbf{N}$ & $\mathbf{P}$ & $\mathbf{K}$ & & $\mathbf{F e}$ & Mn & $\mathbf{Z n}$ & $\mathbf{C u}$ \\
\hline \multicolumn{10}{|c|}{ Without seaweed extract (E) } \\
\hline \multirow{4}{*}{$\begin{array}{l}\text { Un- } \\
\text { Inocutation }\end{array}$} & 0 & 1.87 & 0.164 & 1.69 & 0.39 & 85.0 & 42.1 & 17.0 & 8.2 \\
\hline & 200 & 2.19 & 0.190 & 1.78 & 0.49 & 120.5 & 60.3 & 23.7 & 13.1 \\
\hline & 350 & 2.39 & 0.199 & 1.83 & 0.60 & 17.0 & 79.5 & 27.3 & 14.8 \\
\hline & 450 & 2.45 & 0.210 & 1.85 & 0.67 & 263.5 & 96.2 & 28.9 & 15.6 \\
\hline \multirow{4}{*}{ Inocutation } & 0 & 1.97 & 0.266 & 1.77 & 0.46 & 101.4 & 48.3 & 21.7 & 13.8 \\
\hline & 200 & 2.93 & 0.295 & 1.97 & 0.53 & 163.5 & 64.5 & 32.5 & 20.0 \\
\hline & 350 & 3.37 & 0.323 & 2.08 & 0.70 & 244.1 & 95.3 & 41.3 & 28.1 \\
\hline & 450 & 3.44 & 0.354 & 2.12 & 0.74 & 372.5 & 101.4 & 44.5 & 30.0 \\
\hline \multicolumn{10}{|c|}{ With seaweed extract } \\
\hline \multirow{4}{*}{$\begin{array}{l}\text { Un- } \\
\text { Inocutation }\end{array}$} & 0 & 1.92 & 0.210 & 1.75 & 0.41 & 94.0 & 45.2 & 18.5 & 13.3 \\
\hline & 200 & 2.49 & 0.216 & 1.87 & 0.53 & 143.7 & 77.4 & 29.5 & 22.2 \\
\hline & 350 & 2.79 & 0.521 & 1.94 & 0.69 & 201.0 & 79.6 & 34.7 & 30.0 \\
\hline & 450 & 2.86 & 0.256 & 1.98 & 0.73 & 307.5 & 105.6 & 36.9 & 32.5 \\
\hline \multirow{4}{*}{ Inocutation } & 0 & 2.01 & 0.313 & 1.82 & 0.42 & 89.3 & 47.3 & 19.1 & 12.9 \\
\hline & 200 & 3.25 & 0.350 & 2.13 & 0.59 & 162.5 & 103.4 & 37.9 & 34.7 \\
\hline & 350 & 2.85 & 0.376 & 2.28 & 0.73 & 263.0 & 134.1 & 48.5 & 37.4 \\
\hline & 450 & 3.91 & 0.390 & 2.30 & 0.79 & 395.2 & 145.2 & 51.2 & 44.3 \\
\hline \multicolumn{10}{|c|}{ ANOVA } \\
\hline \multirow{7}{*}{$\begin{array}{l}\text { LSD } \\
\text { at } 0.05\end{array}$} & E & 0.23 & 0.131 & 0.22 & 0.01 & 3.70 & 4.20 & 0.90 & 0.12 \\
\hline & B & 0.12 & 0.111 & 0.11 & 0.02 & 2.10 & 1.70 & 1.70 & 0.22 \\
\hline & $\mathrm{S}$ & 0.23 & 0.131 & 0.10 & 0.01 & 2.50 & 2.50 & 1.10 & 0.42 \\
\hline & $\mathrm{E} \times \mathrm{B}$ & 0.24 & 0.121 & 0.11 & 0.04 & 3.11 & 1.80 & 1.50 & 0.64 \\
\hline & $\mathrm{E} \times \mathrm{S}$ & 0.10 & 0.140 & 0.09 & 0.01 & 4.80 & 3.40 & 1.00 & 0.36 \\
\hline & $\mathrm{B} \times \mathrm{S}$ & 0.15 & 0.124 & 0.10 & 0.03 & 2.34 & 2.90 & 1.10 & 0.23 \\
\hline & $\mathrm{E} \times \mathrm{B} \times \mathrm{S}$ & 0.10 & 0.122 & 0.13 & 0.05 & 2.22 & 4.10 & 1.50 & 0.25 \\
\hline
\end{tabular}

$* \mathrm{PDB}=\mathrm{P}$-dissolving bacteria 
Meanwhile, such favorable effect was extended to the combined treatments at the highest rate of sulphur $\left(450 \mathrm{~kg} \mathrm{fed}^{-1}\right.$, being insignificant difference with the sulphur rate of $350 \mathrm{~kg} \mathrm{fed}^{-1}$ ) due to improving soil physical and chemical properties that positively affected the nutrients availability as well as maintaining a suitable soil moisture regime, which showed a pronounced positive effect on the biological activity in soil, Also, the integrated action of the bio-fertilizer and S-transformation to $\left(\mathrm{H}_{2} \mathrm{SO}_{4}\right)$, besides the possible released phosphate ion by sulphate ions was, in general, extending parallel close to the corresponding nutrients contents in the plant tissues (El-Tapey and Hassan, 2002). Moreover, the interaction between elemental sulphur and P-dissolving bacteria was significant and the best combination dose was at $450 \mathrm{~kg} \mathrm{fed}^{-1} \mathrm{~S}$ with insignificant differences with $350 \mathrm{~kg} \mathrm{fed}^{-1} \mathrm{~S}$, which gave the maximum nutrient content. This confirm the synergism between phosphorus and sulphur (Varavipur et al., 1999).

\section{Yield and its attributes}

Data presented in Table 8 revealed that the head diameter, 100 seed weight, seed yield and some parameters of seed quality (oil and protein contents) were substantially improved by the application of elemental sulphur in combination with either P-dissolving bacteria or seaweed extract. That, means the aforementioned best vegetative growth characters were positively reflected on sunflower yield and its attributes and returned on increasing both head diameter, 100 seed weight and seed yield as well as their quality parameters (i.e., seed contents of oil and protein) as shown in Tables 7 and 8.

Regarding to the combination treatments between elemental sulphur, Pdissolving bacteria and seaweed extract application, there was a significant effect at both rates of sulphur 350 and $450 \mathrm{~kg} \mathrm{fed}^{-1}$ in combination with either Pdissolving bacteria or seaweed extract. These applied treatments enhanced dry matter, seed yield and yield components of sunflower, however, the maximum dry matter weight, head diameter and yield components were achieved at rates of sulphure 350 and $450 \mathrm{~kg} \mathrm{fed}^{-1}$ in combination with P-dissolving bacteria and seaweed extract.

The highly significant enhancement of sulphur on the oil content of sunflower seed due to responses an essential component in some essential amino acids such as cystein and methionine for protein synthesis (Malhi et al., 2007). Depending upon the presented data in Table 8 , oil and protein contents of sunflower seed have been found to be optimized in case of combination with seaweed extract as foliar application. The beneficial effect of seaweed extract on terrestrial plants includes improving the overall growth, yield and the ability to stand with adverse environmental conditions (Asirselvin et al., 2004 and El-Said et al., 2011). Being greater magnitude of 33.87 and $23.56 \%$ was occurred at the combined treatment of sulphur at rate of $450 \mathrm{~kg} \mathrm{fed}^{-1}+\mathrm{P}$-dissolving bacteria and seaweed extract for seed content of protein and oil, respectively, mainly due to greater stimulating action of seaweed extract in the synthesis of sulphur containing protein and also localization of micronutrients in protein bodies as discrete particularly in seed as well as higher rate of translocation of them in presence of sulphur from the root Egypt. J. Soil Sci. 53, No. 1 (2013) 
to seed via shoot meristem resulting increased transaction and translocation with reduced rate of RNA degradation (Sharma et al., 1990).

TABLE 8 . Effect of applied treatments on yield and its attributes .

\begin{tabular}{|c|c|c|c|c|c|c|}
\hline *PDB (B) & $\begin{array}{c}\text { E-Sulphur(S) } \\
\quad\left(\mathrm{kg} \mathrm{fed}^{-1}\right)\end{array}$ & $\begin{array}{c}\text { Head } \\
\text { diameter } \\
(\mathrm{cm})\end{array}$ & $\begin{array}{l}\text { Seed yield } \\
\left(\text { ton fed }^{-1}\right)\end{array}$ & $\begin{array}{l}100 \text { seeds } \\
\text { weight }(g)\end{array}$ & $\begin{array}{c}\text { Seed oil } \\
\left(\mathrm{kg} \mathrm{fed}^{-1}\right)\end{array}$ & $\begin{array}{c}\text { Seed } \\
\text { protein } \\
(\%)\end{array}$ \\
\hline \multicolumn{7}{|c|}{ Without seaweed extract $(\mathrm{E})$} \\
\hline \multirow{4}{*}{$\begin{array}{c}\text { Un- } \\
\text { Inocutation }\end{array}$} & 0 & 9.47 & 0.84 & 3.65 & 137.4 & 8.45 \\
\hline & 200 & 10.88 & 1.09 & 4.70 & 148.0 & 10.93 \\
\hline & 350 & 11.47 & 1.25 & 55.4 & 155.1 & 12.59 \\
\hline & 450 & 12.70 & 1.27 & 5.71 & 156.9 & 12.71 \\
\hline \multirow{4}{*}{ Inocutation } & 0 & 9.57 & 0.94 & 4.75 & 140.2 & 9.49 \\
\hline & 200 & 11.14 & 1.18 & 5.55 & 158.6 & 11.87 \\
\hline & 350 & 13.23 & 1.35 & 6.65 & 170.1 & 13.50 \\
\hline & 450 & 13.93 & 1.38 & 6.60 & 173.4 & 13.67 \\
\hline \multicolumn{7}{|c|}{ With seaweed extract } \\
\hline \multirow{4}{*}{$\begin{array}{c}\text { Un- } \\
\text { Inocutation }\end{array}$} & 0 & 8.91 & 0.92 & 4.45 & 139.5 & 9.24 \\
\hline & 200 & 10.78 & 1.17 & 5.35 & 156.8 & 11.78 \\
\hline & 350 & 12.81 & 1.34 & 5.90 & 168.9 & 13.48 \\
\hline & 450 & 14.95 & 1.39 & 6.45 & 171.5 & 13.55 \\
\hline \multirow{4}{*}{ Inocutation } & 0 & 10.30 & 1.09 & 5.25 & 143.1 & 10.96 \\
\hline & 200 & 12.78 & 1.28 & 6.35 & 166.0 & 12.84 \\
\hline & 350 & 14.81 & 1.44 & 7.40 & 181.4 & 14.15 \\
\hline & 450 & 16.89 & 1.56 & 7.90 & 183.7 & 15.31 \\
\hline \multicolumn{7}{|c|}{ ANOVA } \\
\hline \multirow{7}{*}{$\begin{array}{l}\text { LSD } \\
\text { at } 0.05\end{array}$} & $\mathrm{E}$ & 1.21 & 0.02 & 0.12 & 1.3 & 0.09 \\
\hline & B & 2.00 & 0.20 & 0.13 & 1.5 & 0.84 \\
\hline & $\mathrm{S}$ & 1.64 & 0.03 & 0.11 & 1.6 & 0.62 \\
\hline & $\mathrm{E} \times \mathrm{B}$ & 1.36 & 0.02 & 0.11 & 1.4 & 0.73 \\
\hline & $\mathrm{E} \times \mathrm{S}$ & 1.55 & 0.05 & 0.10 & 1.7 & 0.64 \\
\hline & $\mathrm{B} \times \mathrm{S}$ & 1.64 & 0.04 & 0.13 & 1.3 & 0.72 \\
\hline & $\mathrm{E} \times \mathrm{B} \times \mathrm{S}$ & 1.54 & 0.33 & 0.12 & 1.2 & 0.71 \\
\hline
\end{tabular}

$* \mathrm{PDB}=\mathrm{P}$-dissolving bacteria

\section{Conclusions}

It is noteworthy to mention that data obtained are of the importance in such studied slightly alkaline sandy clay loam soil calcareous in nature, owing to the effective role of the exerted a positive effect on soil fertility status, but also on the different soil properties. Such amelioration in physical, chemical and biological was reflected positively on the sunflower seed yield with high quality as well as chemical constituents of seed (oil and protein). Also, the applied such bio-fertilizer, inorganic soil amendments with foliar seaweed extract had a positive agronomic value due to its capacity to gradually liberate available plant nutrients and to improve soil characteristics with increasing in total bacterial count, $\mathrm{CO}_{2}$ evolution and soil microbiological activity. 


\section{References}

Abbaspour, A., Baligar, V.C. and Shariatmadari, H. (2004) Effect of steel converters as iron fertilizer and soil amendment in some calcareous soils. J. Plant Nutr. 27: 377394.

Abdallah, M., Dubousset, L., Meurit, F., Etienne, P., Avice, J.C. and Qurry, A. (2010) Effect of mineral sulphur availability on nitrogen and sulphur uptake and remobilization during the vegetative growth of Barssica napus L. J. of Experimental Botany 123: 1-12.

Abdel-Aziz, El-Set and El-Shafie, A.I. (2005) Response of soybean to foliar application of phosphatic fertilizer and some micronutrients. Egypt. J. Appl. Sci. 20 (5B): 696719.

Abdel-Mawgoud, A.M.R., Tantaway, A.S., Hafez, Magda M. and Habib, Hoda A.M. (2010) Seaweed extract improves growth, yield and quality of different watermelon hybrids. Research J. of Agric. and Biol. Sci. 6 (2): 161-168.

Abdou, A.S., Al-Darwish, F.H., Maher, E.S., El-Tarabily, K.A. , Azirun, M. S. and Rahman, M. M. (2011) Effects of elemental sulfur, phosphorus, micronutrients and Paracoccus versutus on nutrient availability of calcareous soils. Aust. J.Crop Sci. 5 (5): 554-561

Abdou, A. S., Maher, E.S., El-Tarabily, K.A., Azirun, M.S. and Rahman, M.M. (2011) Effect of elemental sulfur application on ammonia volatilization from surface applied urea fertilizer to calcareous sandy soils. Aust. J. Crop Sci. 5 (5): 611-619.

Alef, K. (1995) Dehydrogenase activity. In: "Methods in Applied Soil Microbiology and Biochemestry”, K., Alef and Nannipierip (Ed.), Academic Press, New York, USA.

Ashmay, S.H., Shaban, Kh.A. and Abd El-Kader, M.G. (2008) Effect of mineral nitrogen, sulphur, organic and bio-fertilizers on maiz productivity in saline soil of Sahl El-Tina. Minufia. J. Agric. Res. 33 (1):195-209.

Asirselvin, K.R., James, J.E. and Saravana, S.B. (2004) Comparative studies on the impact of seaweed and seagrasses liquid fertilizer on the chlorophyll content of Zea mays. Seaweed Research and Utilisation 26: 167-170.

Atilgan, A., Coskan, A., Alagoz, T. and Oz, H. (2008) Application level of chemical and organic fertilizers in the greenhouses of Mediterranean Region and its possible effects. Asian J. Chem. 20: 3702-3714.

Awadalla, A.A., Salib, M.M. and Ibrahim, S.B. (2003) Response of maize yield grown on calcareous soil to some organic and inorganic amendments under irrigation with saline drainage water. Egypt. J. Appl. Sci. 18 (1): 366-381.

Azer, Sohair A., Awad, M.A., Sadek, Jaklin G., Khalil, F.A. and El-Aggory, Eglal M.A. (2003) A comparative study on the effect of elemental $\mathrm{S}$ and biophosphoric fertilizers on the response of faba bean to P fertilization. Egypt. J. Appl. Sci. 18: 324 363.

Egypt. J. Soil Sci. 53, No. 1 (2013) 
Azzam, Clara R. and Omran, Samya E.H. (2005) The promotive effect of PDB biofertilizer on growth, enzymatic activity and bio-chemical changes of sunflower (Helianthus annun L) plants sprayed with micronutrients. The $3^{\text {rd }}$ Conf. of Recent Technologies in Agric. Fac. of Agric., Cairo Univ., Giza, 14-16 November 2: 255267.

Bacilio, M., Vazquez, P. and Bashan, Y. (2003) Alleviation of noxious effects of cattle ranch composts on wheat seed germination by inoculation with Azospirillum spp. Biol. Fertil. Soils 38: 261-266.

Bolland, M.D.A. (1997) Comparative phosphorus requirement of canola and wheat. $J$. Plant Nut. 20: 813-829.

Chapman, V.J. and Chapman, D.J. (1980) "Seaweeds and their Uses", $3^{\text {rd }}$ ed., Chapman and Hall, New York, USA.

Di, C.R., Giulian, M.M., Rotunno,T., De Caro, A. and Flagel, Caterina Z. (2007) Influence of salt stress on seed yield and oil quality of two sunflower hybrids. Ann.of Appl. Biology 151 (2):145-154.

El-Said, Aml, E.A., Farouk, S. and Abd El-Ghany, H.M. (2011) Evaluation of different seed priming on seedling growth, yield and quality component in two sunflower (Helianthus annuns L.) cultivars. Trends in Applied Sci. Res. 6 (9): 977-991.

El-Tapey, H.M.A. and Hassan, H.M. (2002) Effect of water salinity and zinc applications on zinc mobility and growth of sunflower and sudangrass plants grown on Nile alluvial and calcareous soils. Egypt. J. Appl. Sci. 17(12): 480-849.

Erdal, I., Kepenek, K. and Kızılgoz, I. (2004) Effect of foliar iron applications at different growth stages on iron and some nutrient concentrations in strawberry cultivars. Turk. J. Agric. Forest 28: 421-427.

Gomez, K.A. and Gomez, A.A. (1984) "Statistical Procedures for Agricultural Research”, John Willey \& Sons, New York, USA.

Issam, I.B. and Sayegh, A.H. (2007) "Methods of Analysis for Soil of Arid and Semiarid Regions", FAO, Rome, Italy.

Kacar, B. and Katkat, A.V. (2007) "Plant Nutrition", $3^{\text {rd }}$ ed., Nobel Press, Ankara, Turkey.

Kaplan, M., Omran, S., Kader, I. and Koncz, J. (2005) Heavy metal accumulation in calcareous soil and sorghum plants after addition of sulphur-contanting wastes as a soil amendment in Turkey. Agric. Ecosyst. Environ. 111: 41-46.

Khatoon, A., Qureshi, M.S. and Hussain, M.K. (2000) Effect of salinity on some yield parameters of sunflower (Helianthus annuus L.). Inter. J. Agric. Biol. 2 (4): 382-384.

Makovacki, N. and Milic, V. (2001) Use Azotobacter chroococcum as potentially useful in agricultural application. Ann. Microbiology 51:145-158. 
Malhi, S.S., Gan, Y. and Raney, J.P. (2007) Yield seed quality and sulphur uptake of Brassica oilseed crops in response of sulphur fertilization. Agron. J. 99: 570-577.

Marschner, H. (1995) “Mineral Nutriton of Higher Plants”, $2^{\text {nd }}$ ed., Academic Pres, San Diago, USA.

Mohammed, S.S. (2004) Assessment of the relative effectiveness for some organic materials conjucted with mineral nitrogen on soil fertility status, yield and quality of wheat grown on a newly cultivated soil. Egypt. J. Appl. Sci. 19 (3): 298-310.

Motior, M.R., Abdou, A.S., Fareed, H.A.D. and Sofian, M.A. (2011) Responses of sulfur, nitrogen and irrigation water on Zea mays growth and nutrients uptake. Aust. J. Crop Sci. 5 (3): 347-357.

Nassar, K.E., Osman, A.O., El-Kholy, M.H., Madiha, M. and Badran, N. (2002) Effect of seed coating with some micronutrients on faba bean (Vicia faba L.). II. Effect on yield attributes and mineral composition. Egypt. J. Soil Sci. 42 (3): 363.

Neilsen, D., Hogue, E.J., Hoyt, P.B. and Drought, B.G. (1993) Oxidation of elemental sulfur and acidification of calcareous orchard soils in southern British Columbia. Can. J. Soil Sci. 73:103-114.

Omran, Samya E.H. and Azzam, Clara R. (2007) Effect of sulphur, inoculation with Pdissolving bacteria and P-foliar application on two canola (Brassica napus L.) varieties. Egypt. J. Soil Sci. 47(4): 321-333.

Page, A.I., Miller, R.A. and Keeney, D.R. (1982) "Methods of Soil Analysis. Part 2: Chemical and Microbiological Properties", $2^{\text {th }}$ ed., Amer. Soc. of Agron., Madison, Wisconsin, USA

Patel, J.R. and Shelke, R.B. (1998) Effect of farmyard manure, phosphorus and sulphur on growth, yield and quality of Indian mustard (Brassica juncea). Indian J. of Agron. 43:713-717.

Saleh, M.E. (2001) Some agricultural applications for biologically-produced sulfur recovered from sour gases. I. Effect on soil nutrients availability in highly calcareous soils. In: International Symposium on Elemental Sulfur for Agronomic Application and Desert Greening. United Arab Emirates University, Feb. 24-25, 2001, Abu Dhabi, UAE,

Sangeetha, V. and Thevanathan, R. (2010) Biofertilizer potential of traditional and panchagavya amended with seaweed extract. J. of Amer. Sci. 6 (2):61-67.

Shaban, Kh.A. and Omar, M.N.A. (2006) Improvement of maize yield and some soil properties by using nitrogen mineral and PGPR group fertilization in newly cultivated saline soils. Egypt. J. Soil Sci. 46 (3): 329-342.

Sharma, U.C., Gangwar, M.S. and Shrivastava, P.C. (1990) Effect of zinc and sulphur on nutrient uptake and yield of mustard. J. Indian Soc. Soil Sci. 38: 696-701.

Shehata, S. M. (1972) Evaluation of some biological tests as parameters for microbial activates related to soil fertility. Ph. D. Thesis, Fac. Agric., Cairo Univ., Egypt.

Egypt. J. Soil Sci. 53, No. 1 (2013) 
Thirumaran, G., Arumugam, M., Arumugam, R. and Anantharaman, P. (2009) Effect of seaweed liquid fertilizer on growth and pigment concentration of Cyamopsis tetrogonolaba (L.) Taub. American-Eurasian J. of Agron. 2 (2): 50-56.

Upasami, R.R. and Shama, H.C. (1986) Effect of nitrogen and sulphur on some growth parameters, evapotranspiration moisture use efficiency of mustard under dry land conditions. Indian J. Agron. 31: 222-228.

Varavipur, M., Hassan, R. and Singh, D. (1999) Effect of applied phosphorus, sulphur and zinc on yield and uptake parameter of wheat and soybean grown on a loamy sand soil. Indian J. Agric. 69: 1-4.

Verkleij, F.N. (1992) Seaweed extract in agriculture and horticulture: A review. Biological Agric. and Horti. 8: 309-324.

Wassif, M.M., Elgala, A.M., Mostafa, M.A. and El-Maghraby, S.E. (1993) Effect of elemental sulphur and water salinity in two calcareous soils. $2^{\text {nd }}$ African Soil Sci. Soc. Conf. Proc., Nov. 1993, Cairo, Egypt.

Yang, Z.H., Oven, K.S., Haneklaus, S., Singh, B.R. and Schnug, E. (2010) Elemental sulfur oxidation by Thiobacillus spp. and aerobic heterotrophic sulfur-oxidizing bacteria. Pedosphere 20 (1):71-79.

(Received 9/12/2012

accepted 30/6/2013) 


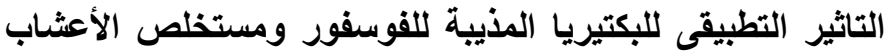

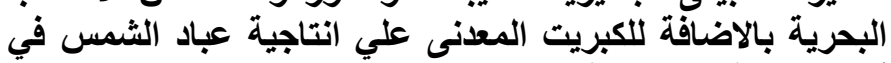 أرض ملحية مستصلحة حليثان المعان \\ نادر رمزي حبشي و منيرة معوض بشارة

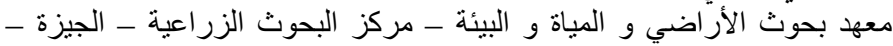

أجريت تجربة حقلية علي تربة رملية طينية طميية في نطاق الأراضي المستصلحة حديثا

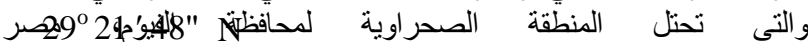

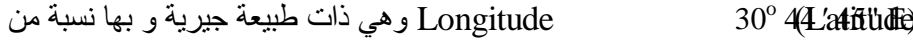

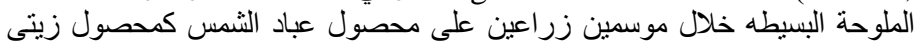
(Helianthus annuns, cv Hysun 336)

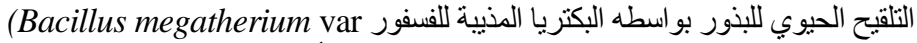
1,0 phosphaticum)

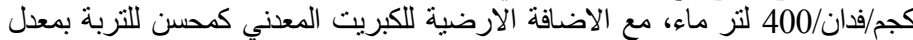

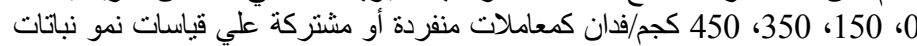

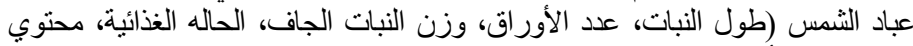

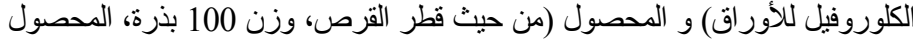

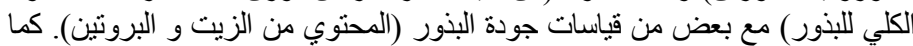

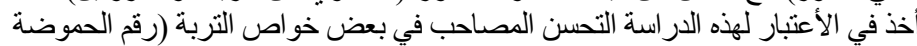

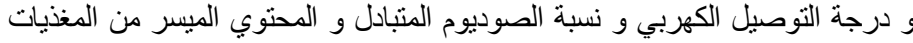

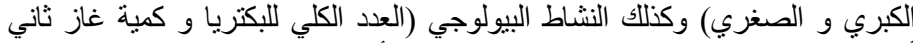

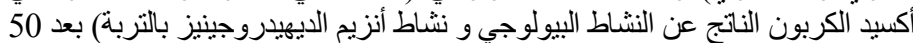

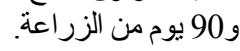

أوضحت النتائج أن هناك تحسن فى صفات التربة و الذي أنعكس بطريقة إيجابية

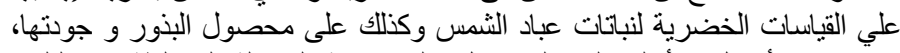

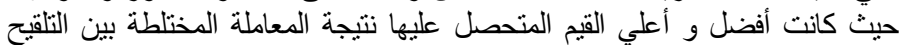

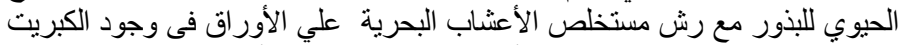

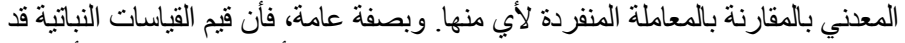

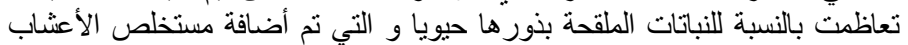

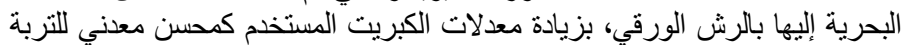

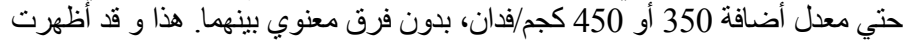

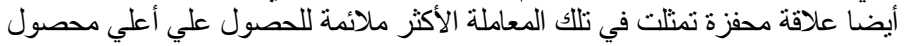

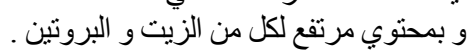

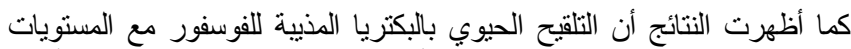

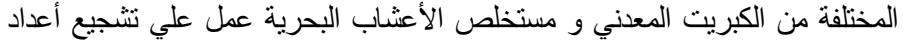

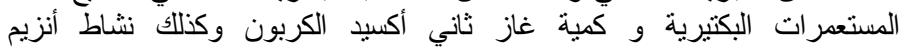
الديهيدروجينيز في التربة بمنطقة الجذور عند 50 و 90 يوم من الزئي الكربون وكة.

لذا بمكن التوصية باستخدام التسميد الحيوي بالبكتريا المذيبة للفسفوروالاضافة التبافية

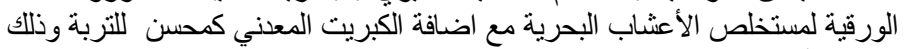

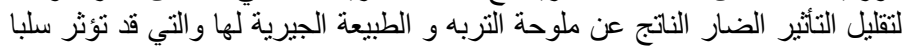
علي أنتاجية و جودة محصول عباد الثمس .

Egypt. J. Soil Sci. 53, No. 1 (2013) 